\title{
Studies on Organomercury(II) Complexes of Isoniacinamide
}

\author{
Sangeeta Bhatia, N. K. Kaushik* \\ Department of Chemistry, University of Delhi, Delhi 110007, India \\ G. S. Sodhi \\ Department of Chemistry, SGTB Khalsa College, University of Delhi, Delhi 110007, India \\ Z. Naturforsch. 43b, 318-322 (1988); received December 1, 1987 \\ Isoniacinamide, Organomercurals, Bonding Mode, Thermal Studies, Antibacterial Activity \\ Organomercury(II) complexes involving isoniacinamide(I) of the type, $\mathrm{RHgCl}_{(\mathrm{L})}(\mathrm{II})$ [ $\mathrm{R}=$ \\ phenyl, $o$-, $p$-hydroxyphenyl $\left(o-, p\right.$ - $\left.\mathrm{HOC}_{6} \mathrm{H}_{4}\right), p$-acetoxyphenyl $\left(p\right.$-AcOC $\left.\mathrm{AC}_{6} \mathrm{H}_{4}\right), 2$-furyl $\left(2-\mathrm{C}_{4} \mathrm{H}_{3} \mathrm{O}\right)$; \\ $\mathrm{L}=$ isoniacinamide] have been synthesized and characterized. Conductance measurements indicate \\ that the complexes are non-electrolytes. From IR and UV spectral studies it is concluded \\ that isoniacinamide is coordinated to the mercury(II) ion through the ring nitrogen atom. \\ ${ }^{1} \mathrm{H}$ and ${ }^{13} \mathrm{C}$ NMR support the stoichiometry of the complexes. Fluorescence studies have \\ been made for $o$-, $p$ - $\mathrm{HOC}_{6} \mathrm{H}_{4} \mathrm{HgCl}(\mathrm{L})$ complexes. For $\mathrm{C}_{6} \mathrm{H}_{5} \mathrm{HgCl}(\mathrm{L}), p$ - $\mathrm{HOC}_{6} \mathrm{H}_{4} \mathrm{HgCl}(\mathrm{L})$ \\ and $p-\mathrm{AcOC}_{6} \mathrm{H}_{4} \mathrm{HgCl}(\mathrm{L})$ complexes, thermal studies (TG and DSC) have been carried out and \\ relevant kinetic and thermodynamic parameters for thermal degradation have been enumerated. \\ The fragmentation pattern of the complexes has been analysed on the basis of mass spectra. The \\ $\mathrm{C}_{6} \mathrm{H}_{5} \mathrm{HgCl}(\mathrm{L})$ and $p-\mathrm{AcOC}_{6} \mathrm{H}_{4} \mathrm{HgCl}(\mathrm{L})$ complexes have been screened for antibacterial activity.
}

\section{Introduction}

Isoniacinamide functions are a constituent of the pyridine nucleotides, which occupy a central role as hydrogen transferring coenzymes. The pyridine ring in the coenzymes is attached in a $\mathrm{N}$-glycosidic linkage to ribose [1]. The interest in the metal complexes of isoniacinamide has arisen because of the fact that although it is a polyfunctional ligand, its bonding mode to the metal ions remains the same as that in the biological system. In the present complexes, too, it is coordinated to mercury(II) ion through the pyridine nitrogen.

Further, isoniacinamide is an antibiotic substance and manifests significant therapeutic effects [2]. It is expected that the antibiotic action of a drug is enhanced in the presence of metal ions, since the introduction of metal complexes in vivo prolongs the metabolism of the drug and leads to a more pronounced biological effect. With this aim, we undertook the synthesis and characterization of some organomercury(II) complexes of isoniacinamide and screened some representative samples for antibacterial activity. This is a sequel to our investigation of metal ion-biomolecule interactions [3-6].

\footnotetext{
* Reprint requests to Dr. N. K. Kaushik.

Verlag der Zeitschrift für Naturforschung, D-7400 Tübingen 0932-0776/88/0300-0318/\$ 01.00/0
}

\section{Experimental}

The following instruments were used: Elico conductivity bridge, model CM-82 for conductance measurements; Shimadzu infrared spectrophotometer, IR-435 for IR spectra; Perkin-Elmer UV-VIS spectrometer, model 554 for UV spectra; Jeol FX-200 FT-NMR spectrometer for ${ }^{1} \mathrm{H}$ and ${ }^{13} \mathrm{C}$ NMR spectra; Jasco FP-500 spectrofluorometer for fluorescence studies; G-70, SETARAM (Lyon, France) for recording TG curves in air at a heating rate of $8^{\circ} \mathrm{min}^{-1}$. Du Pont device for recording DSC curves up to $673 \mathrm{~K}$, at a heating rate of $8^{\circ} \mathrm{min}^{-1}$. Mass spectra were recorded at Central Drug Research Institute, Lucknow, India.

Nitrobenzene was purified for conductance measurements by the method of Fay et al. [7]. $\mathrm{C}_{6} \mathrm{H}_{5} \mathrm{HgCl}$ [8], $o-, p-\mathrm{HOC}_{6} \mathrm{H}_{4} \mathrm{HgCl}$ [9], $p-\mathrm{AcOC}_{6} \mathrm{H}_{4} \mathrm{HgCl}$ [10] and $2-\mathrm{C}_{4} \mathrm{H}_{3} \mathrm{OHgCl}[11]$ were synthesized by standard methods. Isoniacinamide was purchased from $\mathrm{Al}-$ drich Chemical Co., Inc., USA.

\section{Preparation of complexes}

A solution of isoniacinamide $(0.01 \mathrm{~mol})$ in $25 \mathrm{ml}$ THF was added slowly to a solution of $\mathrm{RHgCl}$

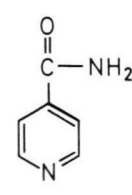

I<smiles></smiles>

II 
$(0.01 \mathrm{~mol})$ in $25 \mathrm{ml} \mathrm{THF}$. The contents were stirred for about $2 \mathrm{~h}$ at room temperature and filtered. The $\mathrm{RHgCl}(\mathrm{L})$ complexes were precipitated on addition of petroleum ether to the filtrate and recrystallized from acetone.

\section{Results and Discussion}

Satisfactory results of elemental analysis and spectral studies reveal that the complexes are of good purity. This is also supported by TLC. The complexes are white in colour and soluble in THF, DMSO, and acetone. Conductance measurements in $10^{-3} \mathrm{M}$ solution are of the order of $0.50 \mathrm{ohm}^{-1} \mathrm{~cm}^{2} \mathrm{~mol}^{-1}$, indicating that the complexes are non-electrolytes. Some physical characteristics and elemental analysis data are presented in Table I.

\section{Infrared spectra}

Isoniacinamide has three bonding sites, i.e. heterocyclic nitrogen, amido nitrogen and carbonyl oxygen. The ligand may be coordinated to the metal by one or more of these.

In complexes of carbonyl donors a significant negative shift in carbonyl frequency takes place [12]. In the present study, the carbonyl stretching frequency absorbs at $\sim 1670 \mathrm{~cm}^{-1}$, both in case of ligand and metal complexes. The same is true for $v(\mathrm{NH})$ of the amido group which absorbs at $\sim 3325 \mathrm{~cm}^{-1}$ in case of the ligand as well as the metal complexes. This rules out the possibility of bonding through the carbonyl oxygen or the amido nitrogen.

On the other hand, IR frequencies exhibit appreciable perturbation in the fundamental vibrations of the pyridine part of the molecule. Absorption bands at $1590 \mathrm{~cm}^{-1}$ due to $v(\mathrm{C} \cdots \mathrm{C})$ stretching frequency and at $1550 \mathrm{~cm}^{-1}$ due to $v(\mathrm{C} \cdots \mathrm{N})$ stretching frequency of the isoniacinamide molecule are shifted to $\sim 1620$ and $\sim 1600 \mathrm{~cm}^{-1}$, respectively, on complexa- tion [13]. Further, the pyridine ring vibrations of the ligand at 950, 605 and $405 \mathrm{~cm}^{-1}$ also undergo significant positive shifts [14]. In case of metal complexes, these vibrations absorb at $c a .990,630$ and $435 \mathrm{~cm}^{-1}$ indicating that coordination takes place via the pyridine nitrogen only. The $v(\mathrm{Hg}-\mathrm{Cl})$ frequency appears at $\sim 365 \mathrm{~cm}^{-1}$.

\section{UV spectra}

In case of isoniacinamide, a very intense band appears at $256 \mathrm{~nm}(\log \varepsilon 7.1)$ which is attributed to the $\pi-\pi^{*}$ absorptions of the carbonyl group. In the metal complexes this band is shifted to $c a .234 \mathrm{~nm}$ $(\log \varepsilon \sim 5.1)$. In case of metal complexes involving isoniazid [5] which is structurally quite similar to isoniacinamide, but coordinates through the carbonyl group, a positive shift is observed in the absorption band due to the $\mathrm{C}=\mathrm{O}$ chromophore. In the present complexes, the negative shift in $\lambda_{\max }$ value rules out the possibility of bonding through the carbonyl group.

\section{${ }^{1} H$ NMR spectra}

In ${ }^{1} \mathrm{H}$ NMR spectra, the following signals are attributed to the presence of an isoniacinamide moiety in the complexes: $\delta 7.70-7.92\left(\mathrm{~m}, 2 \mathrm{H}, \mathrm{H}_{3.5}\right)$ and $\delta 8.30-8.75\left(\mathrm{~m}, 2 \mathrm{H}, \mathrm{H}_{2.6}\right)$. The latter signal in pure isoniacinamide was observed at $\delta 8.10-8.30$ $(\mathrm{m}, 2 \mathrm{H})$. The downfield shift in case of metal complexes is due to the involvement of the ring nitrogen in complexation. In $p-\mathrm{HOC}_{6} \mathrm{H}_{4} \mathrm{HgCl}(\mathrm{L})$ and $p$ - $\mathrm{AcOC}{ }_{6} \mathrm{H}_{4} \mathrm{HgCl}(\mathrm{L})$ complexes, the resonance signals due to the $\mathrm{C}_{6} \mathrm{H}_{4}$ group and $\mathrm{H}_{3.5}$ of isoniacinamide ligand overlap with each other and a multiplet is observed in the region $\delta 7.0-8.0$. The furyl group in $2-\mathrm{C}_{4} \mathrm{H}_{3} \mathrm{OHgCl}(\mathrm{L})$ analogue is identified by signals at $\delta 6.56(\mathrm{~d}, 2 \mathrm{H}, J 9.8 \mathrm{~Hz})$ and $\delta 7.48(\mathrm{~s}, 1 \mathrm{H})$.

Table I. Physical characteristics and elemental analyses.

\begin{tabular}{llllll}
\hline Complex & $\begin{array}{l}\text { Dec. temp. } \\
{\left[{ }^{\circ} \mathrm{C}\right]}\end{array}$ & $\begin{array}{l}\Lambda^{\mathrm{a}} \\
{\left[\mathrm{C}=1.5 \times 10^{-3} \mathrm{M}\right]}\end{array}$ & $\begin{array}{l}\text { Found (calcd) [\%] } \\
\mathrm{Hg}\end{array}$ & $\mathrm{N}$ & $\mathrm{Cl}$ \\
\hline $\mathrm{C}_{6} \mathrm{H}_{5} \mathrm{HgCl}(\mathrm{L})$ & 122 & 0.48 & $46.15(46.20)$ & $6.47(6.44)$ & $8.00(8.05)$ \\
$o-\mathrm{HOC}_{6} \mathrm{H}_{4} \mathrm{HgCl}(\mathrm{L})$ & 118 & 0.46 & $44.50(44.57)$ & $6.32(6.21)$ & $7.69(7.76)$ \\
$p-\mathrm{HOC}_{6} \mathrm{H}_{4} \mathrm{HgCl}(\mathrm{L})$ & 212 & 0.50 & $44.64(44.57)$ & $6.36(6.21)$ & $7.66(7.76)$ \\
$p-\mathrm{AcOC}_{6} \mathrm{H}_{4} \mathrm{HgCl}(\mathrm{L})$ & 185 & 0.50 & $41.04(40.85)$ & $5.50(5.69)$ & $7.10(7.11)$ \\
$2-\mathrm{C}_{4} \mathrm{H}_{3} \mathrm{OHgCl}(\mathrm{L})$ & 126 & 0.52 & $47.35(47.29)$ & $6.54(6.59)$ & $8.10(8.35)$ \\
\hline
\end{tabular}

\footnotetext{
${ }^{\mathrm{a}} \mathrm{ohm}^{-1} \mathrm{~cm}^{2} \mathrm{~mol}^{-1}$.
} 


\section{${ }^{13}$ C NMR spectra}

In pure isoniacinamide the signals due to $\mathrm{C}_{2.6}$ and $\mathrm{C}_{3.5}$ carbons appear at 146.9 and $123.4 \mathrm{ppm}$, respectively. On complexation, the former signal is shifted to $c a$. $151.5 \mathrm{ppm}$, while the latter remains unaffected. The shift is attributed to the involvement of the pyridine nitrogen in complexation. In isoniacinamide, the carbonyl group shows a signal at $168.6 \mathrm{ppm}$. This value remains unaltered in complexes. The signal due to the $\mathrm{C}_{4}$ carbon appears at $135.4 \mathrm{ppm}$. Table II lists the position of resonance signals observed in the ${ }^{13} \mathrm{C}$ NMR spectra.

\section{Fluorescence studies}

The $o$-, $p$ - $\mathrm{HOC}_{6} \mathrm{H}_{4} \mathrm{HgCl}(\mathrm{L})$ complexes are fluorescent in nature. Hence their fluorescence spectra have been recorded. The absorption band is observed at $244 \mathrm{~nm}(\log \varepsilon 4)$, while the emission band is at $488 \mathrm{~nm}$. Thus, in accordance with the Franck-Condon principle and thermal relaxation of vibrational modes, the fluorescence spectra are observed on the red side of the absorption spectra approximately in a mirror image relationship [15]. A slight distorted in the mirror image pattern arises due to the appearance of a weak band at $312 \mathrm{~nm}(\log \varepsilon 1.5)$ because of the forbidden transitions, $\operatorname{Hg} 6\left({ }^{3} \mathrm{p}_{1}\right) \rightarrow \operatorname{Hg} 6\left({ }^{1} \mathrm{~s}_{0}\right)$ and $J=0 \rightarrow J=0$ [5].

The spectrum is free from anti-Stokes effects. The pattern of the spectrum follows Levschin's rule, indicating that the geometry of the excited state is similar to that of the ground state [16]. The quantum yields of fluorescence, $\emptyset_{\mathrm{f}}$, calculated by the relative method [17], using anthracene as the reference, are as follows: $o-\mathrm{HOC}_{6} \mathrm{H}_{4} \mathrm{HgCl}(\mathrm{L}), 0.65 ; p-\mathrm{HOC}_{6} \mathrm{H}_{4} \mathrm{HgCl}(\mathrm{L}), 0.62$. Since the $\emptyset_{\mathrm{f}}$ values show deviation from unity, it is inferred that fluorescence remains the dominant, but not the exclusive mode of emission. The non-radiative modes like inter-system crossing and internal conversion are likely to be contributing to the emission process.

\section{Thermal studies}

Thermogravimetric (TG) studies have been carried out for $\mathrm{C}_{6} \mathrm{H}_{5} \mathrm{HgCl}(\mathrm{L}), p-\mathrm{HOC}_{6} \mathrm{H}_{4} \mathrm{HgCl}(\mathrm{L})$ and $p$ - $\mathrm{AcOC}{ }_{6} \mathrm{H}_{4} \mathrm{HgCl}(\mathrm{L})$ complexes. The weight loss in each case corresponds to the formation of $\mathrm{HgO}$, which slowly volatilizes beyond $763 \mathrm{~K}$. The order (n) and activation energy $\left(E_{a}\right)$ for the thermal decomposition reaction have been elucidated by the method of Coats and Redfern [18]. The linearization curve is shown in Fig. 1.

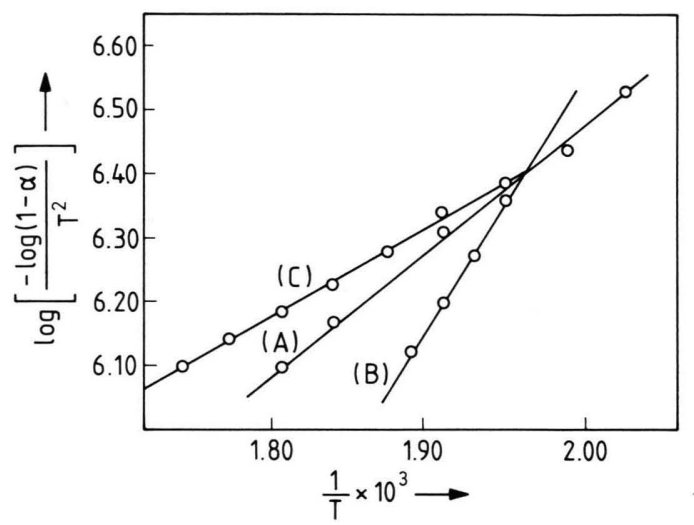

Fig. 1. Kinetic parameters from TG for (A) $\mathrm{C}_{6} \mathrm{H}_{5} \mathrm{HgCl}(\mathrm{L})$; (B) $p-\mathrm{HOC}_{6} \mathrm{H}_{4} \mathrm{HgCl}(\mathrm{L})$; (C) $p-\mathrm{AcOC}_{6} \mathrm{H}_{4} \mathrm{HgCl}(\mathrm{L})$.

The order of reaction in each case is one. A comparison of the activation energy data reveals that $p$ - $\mathrm{AcOC}{ }_{6} \mathrm{H}_{4} \mathrm{HgCl}(\mathrm{L})$ complex has the lowest value of $\mathrm{E}_{\mathrm{a}}$. This may be explained on the basis of the electron withdrawing effect of the acetoxy group, which weakens the $\mathrm{R}-\mathrm{Hg}$ bond, making thermal degradation relatively easy. In case of the $p-\mathrm{HOC}_{6} \mathrm{H}_{4} \mathrm{HgCl}(\mathrm{L})$ complex, the phenolic group is electron donating and the $\mathrm{R}-\mathrm{Hg}$ bond is strengthened. Therefore, the activation energy value in this case is higher than in the unsubstituted $\mathrm{C}_{6} \mathrm{H}_{5} \mathrm{HgCl}(\mathrm{L})$ complex. That $\mathrm{R}-\mathrm{Hg}$

Table II. ${ }^{13} \mathrm{C}$ NMR data.

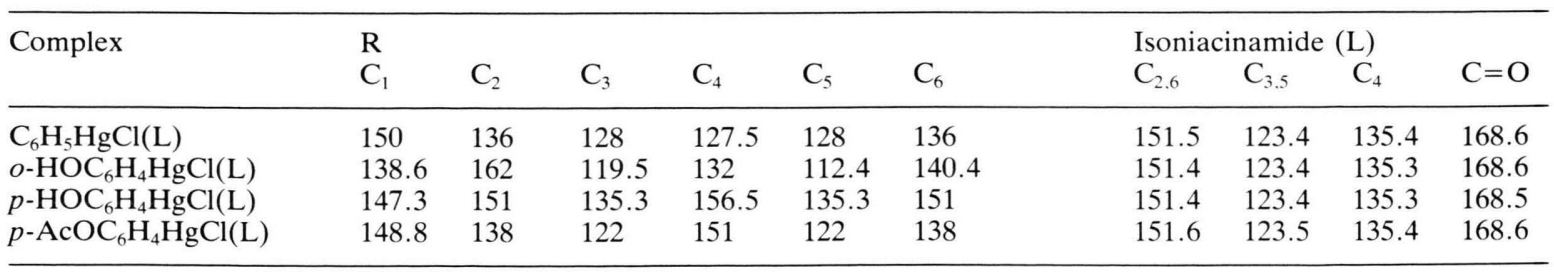


Table III. Thermal data.

\begin{tabular}{|c|c|c|c|c|c|c|c|c|}
\hline Complex & $\begin{array}{l}\text { TG } \\
\text { wt. loss } \\
\text { Found } \\
\text { (calcd) }[\%]\end{array}$ & $\begin{array}{l}\text { Temp. range } \\
{[\mathrm{K}]}\end{array}$ & $n$ & $\begin{array}{l}\mathrm{E}_{\mathrm{a}} \\
{[\mathrm{Kcal} / \mathrm{mol}]}\end{array}$ & $\begin{array}{l}\mathrm{S}^{\neq} \\
{[\text {e.u.] }}\end{array}$ & $\begin{array}{l}\text { DSC } \\
\text { Thermal } \\
\text { effect }\end{array}$ & $\begin{array}{l}\mathrm{T}_{\max } \\
{[\mathrm{K}]}\end{array}$ & $\begin{array}{l}\Delta \mathrm{H} \\
{[\mathrm{cal} / \mathrm{g}]}\end{array}$ \\
\hline $\mathrm{C}_{6} \mathrm{H}_{5} \mathrm{HgCl}(\mathrm{L})$ & $51.8(50.2)$ & $433-563$ & 1 & 9.53 & 6.85 & Endothermic & 506 & 38.68 \\
\hline$p-\mathrm{HOC}_{6} \mathrm{H}_{4} \mathrm{HgCl}(\mathrm{L})$ & $53.8(51.9)$ & $483-533$ & 1 & 17.60 & 14.05 & Endothermic & 502 & 27.45 \\
\hline$p-\mathrm{AcOC}_{6} \mathrm{H}_{4} \mathrm{HgCl}(\mathrm{L})$ & $54.1(51.9)$ & $463-573$ & 1 & 6.54 & 2.86 & Endothermic & 523 & 46.95 \\
\hline
\end{tabular}

bond cleavage is involved in the pyrolysis of the complexes is also indicated by the mass spectra, where peaks for $\mathrm{C}_{6} \mathrm{H}_{5}{ }^{+}, \mathrm{HOC}_{6} \mathrm{H}_{4}{ }^{+}$and $\mathrm{AcOC}_{6} \mathrm{H}_{4}{ }^{+}$fragments have been observed.

The apparent activation entropy [19], $\mathrm{S}^{\neq}$, has a positive value for all the complexes. The $p-\mathrm{HOC}_{6} \mathrm{H}_{4} \mathrm{HgCl}(\mathrm{L})$ complex has the highest value of $\mathrm{S}^{\neq}$, while $p$ - $\mathrm{AcOC}_{6} \mathrm{H}_{4} \mathrm{HgCl}(\mathrm{L})$ has the lowest. Hence, the former decomposes with greatest degree of randomness while the latter with the least.

The TG data are supplemented by differential scanning calorimetry (DSC) studies. The thermal effects on DSC curves are endothermic in nature. The heat of reaction, $\Delta \mathrm{H}$ has been enumerated for the thermal decomposition reaction from DSC studies. Thermal data are presented in Table III.

\section{Mass spectra}

The fragmentation pattern of the complexes shows that the $\mathrm{RHg}^{+}, \mathrm{R}^{+}, \mathrm{HgCl}^{+}$and $\mathrm{Hg}^{+}$ions dominate the mass spectra [20]. The fragmentation of the $\mathrm{RHg}^{+}$portion is similar to that reported earlier [4]. The fragmentation pattern of the ligand portion is shown in Scheme 1. The isoniacinamide molecular ion $1(m / e 122)$ is formed initially. It eliminates an $\mathrm{NH}_{2}$ radical giving fragment 2 ( $m / e$ 106) which subsequently loses $\mathrm{CO}$ to give fragment 3 ( $m / e$ 78), fol-

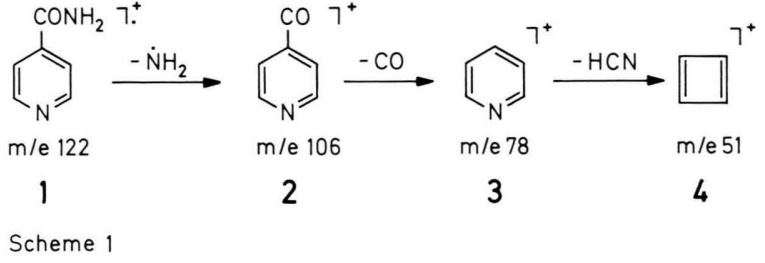

lowed by elimination of $\mathrm{HCN}$, resulting in fragment 4 (m/e 51). The isoniacinamide molecular ion 1 (m/e 122) constitutes the base peak.

\section{Antibacterial activity}

The $\mathrm{C}_{6} \mathrm{H}_{5} \mathrm{HgCl}(\mathrm{L})$ and $p$ - $\mathrm{AcOC}_{6} \mathrm{H}_{4} \mathrm{HgCl}(\mathrm{L})$ complexes were screened against $E$. coli and $P$. pyocyanea bacterial strains at concentrations of 25 and $50 \mu \mathrm{g} \mathrm{ml}^{-1}$. The complexes showed greater inhibition at higher concentration. While both the samples were equally active against $E$. coli, the $p-\mathrm{AcOC}_{6} \mathrm{H}_{4} \mathrm{HgCl}(\mathrm{L})$ analogue showed greater inhibition against $P$. pyocanea. The order of activity against two microorganisms is $P$. pyocanea $>E$. coli.

We thank the University Grants Commission, New Delhi for the award of a research fellowship to one of us (SB).
[1] P. Karlson, Introduction to Modern Biochemistry, 2nd Edn, Academic Press, New York (1965).

[2] A. Grollman and E. F. Grollmann, Pharmacology and Therapeutics, 7th Edn, Lea \& Febiger, Philadelphia (1970)

[3] S. Bhatia, G. S. Sodhi, and N. K. Kaushik, Inorg. Chim. Acta 29, 107 (1985).

[4] S. Bhatia, N. K. Kaushik, and G. S. Sodhi, Inorg. Chim. Acta 127, 141 (1987)

[5] S. Bhatia, N. K. Kaushik, and G. S. Sodhi, J. Inorg. Biochem. 29, 181 (1987).
[6] S. Bhatia, N. K. Kaushik, and G. S. Sodhi, J. Chem. Res. (S) 186 (1987); (M) 1519 (1987).

[7] R. C. Fay and R. N. Lowry, Inorg. Chem. 6, 1512 (1967).

[8] J. F. Kapian and C. Meilick, US Pat. 2,502,222 (1950); C. A. 44, 68,821 (1950).

[9] F. C. Whitmore and E. R. Hanson, Organic Synthesis, Coll. Vol. I, p. 155, Wiley, New York (1932).

[10] H. Gilman and E. B. Middleton, J. Am. Chem. Soc. 43, 2578 (1921).

[11] H. Gilman and G. F. Wright, J. Am. Chem. Soc. 55, 3302 (1933). 
[12] R. C. Paul and S. L. Chadha, J. Inorg. Nucl. Chem. 31, 2753 (1969).

[13] I. S. Ahuja, R. Singh, and C. P. Rai, Trans. Met. Chem. 2, 257 (1977).

[14] P. P. Singh, J. N. Seth, and S. A. Khan, Inorg. Nucl. Chem. Lett. 11, 525 (1975).

[15] E. J. Brown and F. Wokes, The Fluorescence of Solution, Longmans Green, London (1953).

[16] K. K. Rohtagi-Mukharjee, Fundamentals of Photochemistry, Wiley-Eastern, New Delhi (1978).
[17] J. G. Calvert and J. N. Pitts, Photochemistry, Wiley, New York (1966).

[18] A. W. Coats and J. P. Redfern, Nature (London) 201, 68 (1964).

[19] J. Zsakó, J. Phys. Chem. 72, 2406 (1968).

[20] F. Glockling, J. R. Irwin, R. J. Morrison, and J. J. Sweeney, Inorg. Chim. Acta 19, 267 (1976). 